Jurnal Keperawatan Silampari

Volume 2, Nomor 2, Juni 2019

e-ISSN: 2581-1975

p-ISSN: 2597-7482

DOI: https://doi.org/10.31539/jks.v2i2.509

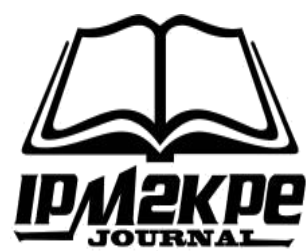

\title{
KOMBINASI HERBAL STEAM BATH DAN MASSAGE TERAPI PADA IBU NIFAS DALAM MENCEGAHPOST PARTUM BLUES
}

\author{
Kristina Maharani ${ }^{1,}$ Choirul Anwar ${ }^{2,}$ Agus Suwandono ${ }^{3}$ \\ Program Kebidanan Sains Terapan Pascasarjana, Poltekkes Kemenkes Semarang 1,2,3 \\ maharanikristina@gmail.com ${ }^{1}$
}

\begin{abstract}
ABSTRAK
Tujuan dari penelitian ini adalah menganalisis efektivitas kombinasi herbal steam bath dan massage terapi sebagai cara mencegah post partum blues ibu nifas. Jenis penelitian quasi experiment dengan desain penelitian pre test and post test control group. Hasil penelitian, herbal steam bath dan massage terapi lebih efektif dibandingkan dengan perawatan nifas konvensional dalam pencegahan post partum blues dengan p-value < 0,05. Simpulan, Herbal steam bath dan massage terapi dapat digunakan sebagai terapi alternatif dalam pencegahan post partum blues.
\end{abstract}

Kata Kunci: Herbal Steam Bath, Massage terapi, Nifas, Postpartum Blues

\section{ABSTRACT}

The purpose of this study was to analyze the effectiveness of a combination of herbal steam bath and massage therapy as a way to prevent post partum blues of postpartum mothers. This type of quasi experiment research design with pre-test and post-test control group. The results of the study, herbal steam bath and massage therapy are more effective than conventional puerperal care in the prevention of post partum blues with a p-value <0.05. Conclusion, Herbal steam bath and massage therapy can be used as an alternative therapy in the prevention of post partum blues.

Keywords: Herbal Steam Bath, Massage therapy, Postpartum Blues, Postpartum Blues

\section{PENDAHULUAN}

Masa nifas (puerperium) merupakan masa kritis bagi ibu dan bayi yang berlangsung selama kurang lebih 40 hari (A.C. de Mouraea, 2016). Pada masa nifas sebaiknya ibu dan bayi mendapatkan 4 kali kunjungan masa nifas, dengan tujuan mencegah, mendeteksi dan menangani komplikasi. Komplikasi yang terjadi pada ibu salah satunya adalah komplikasi secara psikologis. Kesehatan ibu selama periode postpartum dapat terganggu karena perubahan fisik dan psikologis.

Pada ibu nifas ada yang bersemangat menikmati peran barunya dalam mengasuh bayinya, ada yang merasa sedih dan berputus asa sehingga tidak bersedia untuk mengurus bayinya (Moura, 2016). Kondisi ini dapat memicu kejadian postpartum blues. Blues adalah salah satu komplikasi postpartum yang biasanya tidak terdeteksi dan tidak diobati. Post partum blues merupakan hal yang perlu diperhatikan, karena merupakan gangguan kejiwaan (afeksi) yang terjadi pada wanita setelah persalinan. Post partum blues dapat dipengaruhi oleh dua faktor yaitu faktor internal dan faktor eksternal. Faktor internal dipengaruhi oleh adanya fluktuasi hormone estrogen, endorphin dan tiroid 
sedangkan faktor eksternal dapat dipengaruhi oleh kebudayaan yang dapat membatasi aktivitas ibu dalam merawat bayinya.

Menurut data WHO melalui penelitian oleh Edwards et al, bahwa Indonesia pada tahun 2006 memiliki prevalensi 22,4\% morbiditas psikiatri dan psikologis periode postpartum dengan skor EPDS $>10$ (Gibson, 2009). Tingkat prevalensi gangguan periode postpartum terbagi menjadi tiga kategori yaitu postpartum blues sebanyak 3075\% (hari ke 3 atau 4), depresi postpartum (dalam waktu 12 bulan) sebanyak 10-15\% dan postpartum psikosis sebanyak 0,1-0,2\% (dalam waktu 2 minggu).

Menurut data WHO melalui penelitian oleh Edwards et al, bahwa Indonesia pada tahun 2006 memiliki prevalensi 22,4\% morbiditas psikiatri dan psikologis periode postpartum dengan skor $E P D S>10$. Tingkat prevalensi gangguan periode postpartum terbagi menjadi tiga kategori yaitu postpartum blues sebanyak 30-75\% (hari ke 3 atau 4), depresi postpartum (dalam waktu 12 bulan) sebanyak 10-15\% dan postpartum psikosis sebanyak 0,1-0,2\% (dalam waktu 2 minggu) (Gibson, 2009).

Kesehatan psikologi jarang diperhatikan pada asuhan nifas konvensional, sedangkan kesehatan jiwa akan berpengaruh pada kesehatan fisik yang tidak dapat dipisahkan, sehingga diperlukan upaya dalam penanganan depresi pada pasien post partum. Upaya penanganan depresi postpartum meliputi upaya preventif, promotif, kuratif dan rehabilitative. Tindakan promotif preventif yang dapat diberikan adalah penjelasan, meningkatkan peran serta suami, kunjungan rumah, memenuhi kebutuhan dasar masa nifas khususnya meningkatkan kebugaran fisik seperti ambulasi dan senam nifas. Upaya lain penanganan depresi postpartum meliputi pengobatan, terapi psikologi, psikososial dan penanganan tanpa obat seperti latihan, akupunktur dan massage terapi (Kirana, 2016).

Telah terbukti melalui riset bahwa pengobatan alternatif menjadi pilihan yang aman dan minim efek samping jika dibandingkan dengan pengobatan konvensional (Manurung, 2011). Segala yang bersifat natural tidak memiliki efek samping negatif terhadap fungsi tubuh manusia.

Herbal steam bath merupakan mandi uap tradisional dengan rempah alami untuk meningkatkan kenyamanan ibu, menurunkan depresi, meningkatkan fungsi jantung ibu sehingga peredaran darah menjadi lancar dengan harapan akan membantu memulihkan kondisi fisik dan mental ibu.

Metode alternative lain yang memiliki tujuan hampir sama dengan herbal steam bath adalah massage. Massage merupakan salah satu metode alternatif yang sangat aman dan memiliki manfaat yang luas terhadap pemulihan tubuh. Massage meningkatkan serotonin sehingga menurunkan hormone kortisol dan menurunkan depresi. Massage juga meningkatkan dopamine sehingga menurunkan norepinephrine dan menurunkan kecemasan. Sehingga daya tahan tubuh ibu nifas akan meningkat dengan harapan akan membantu memulihkan kondisi fisik dan mental ibu.

\section{METODE PENELITIAN}

Penelitian ini merupakan jenis penelitian quasi experiment dengan desain penelitian pre test and post test control group. Perlakuan yang diberikan bertujuan menganalisis perubahan yang timbul dari adanya intervensi herbal steam bath dan massage terapi dan kelompok kontrol diberikan perawatan nifas konvensional terhadap pencegahan postpartum blues.

Populasi dalam penelitian ini adalah seluruh ibu nifas wilayah kerja puskesmas Mranggen III Kabupaten Demak. Sampel diambil dengan metode purposive sampling. 
Sampel dalam penelitian ini adalah ibu nifas di wilayah kerja puskesmas Mranggen III Kabupaten Demak.

Pada penelitian ini jumlah sampelnya kelompok kontrol dan intervensi sebesar 30 responden. Teknik pengambilan sampel yang digunakan adalah teknik Non Probability Sampling. Cara pengambilan sampel yaitu dengan purposive sampling. Alat pengumpulan data Kuesioner yang berisi identitas pasien, pendidikan, pekerjaan, umur kehamilan, riwayat kesehatan fisik dan psikososial dan Kuesioner EPDS, merupakan kuesioner yang terdiri dari 10 item pertanyaan untuk mengetahui status depresi pada ibu nifas. EPDS sudah memiliki spesifisitas dan sensitivitas yang tinggi untuk mengukur tingkat depresi pada ibu hamil dan postpartum.

Waktu penumpulan data Intervensi postpartum herbal steam bath dilakukan pada masa nifas selama 1 minggu dengan dosis 2 kali dalam seminggu selama 5-20 menit, sedangkan massage terapi dilakukan selama 1 minggu sebanyak 2 kali selama 3-5 menit.

Analisis data menggunakan analisis univariat, bivariate dan multivariate. Data dalam bentuk presentase mengenai karakteristik responden berdasarkan umur, tingkat pendidikan, pekerjaan, paritas, jenis persalinan. Pengkategorian data sesuai dengan alat ukur yang telah ditentukan yang selanjutnya dianalisis untuk mengetahui nilai mean, modus maupun standar deviasi dari setiap variabel yang diukur.

Analisis bivariat dalam penelitian ini sebagai berikut: Untuk mengetahui varian antar kedua kelompok responden apakah sama (homogen) antar kelompok menggunakan uji Levene's. Variabel yang diujikan untuk mengetahui apakah variabel tersebut homogen atau tidak adalah variabel confounding yang terdiri dari umur, pendidikan, pekerjaan, cara persalinan, status ekonomi dan paritas. Variabel umur, pendidikan, pekerjaan, cara persalinan, status ekonomi, dan paritas dikatakan sama atau homogen karena nilai $\mathrm{p}$ (nilai probabilitas) > 0,05, Analisis data memakai uji non parametric, uji beda rerata antara kelompok eksperimen dengan kelompok kontrol diuji dengan menggunakan mann-whitney $u$ test, mengetahui perbedaan rerata skor perlakuan dan kontrol menggunakan uji wilcoxon rank test untuk data yang berdistribusi tidak normal, mengetahui pengaruh intervensi dengan mengetahui perbedaan rerata diantara kelompok perlakuan dan kontrol menggunakan uji independent sample t-tes untuk data yang berdistribusi normal dan menggunakan mann-whitney $u$ test untuk data yang berdistribusi tidak normal.

Analisis Multivariat pada penelitian ini untuk mengukur karakteristik responden yaitu menggunakan uji regresi linear umur, pendidikan, pekerjaan, pendapatan, paritas, cara persalinan.

Ijin etichal clearance penelitian diajukan ke komisi etik penelitian Poltekkes Kemenkes Semarang dan terbit dengan nomor 442/KEPK/Poltekkes-Smg/EC/2018.

\section{HASIL PENELITIAN Analisis Univariat}

Tabel. 1

Distribusi Frekuensi Karakteristik Responden Berdasarkan Usia

\begin{tabular}{ccccc}
\hline \multirow{2}{*}{ Variabel } & \multicolumn{2}{c}{ Kelompok Intervensi } & \multicolumn{2}{c}{ Kelompok Kontrol } \\
\cline { 2 - 5 } & Frekuensi & $\begin{array}{c}\text { Presentasi } \\
\%\end{array}$ & Frekuensi & $\begin{array}{c}\text { Presentasi } \\
\%\end{array}$ \\
\hline $20-35$ & 11 & 73,3 & 12 & 80 \\
\hline$>35$ & 4 & 26,7 & 3 & 20 \\
\hline
\end{tabular}


Berdasarkan tabel 1 menunjukkan bahwa rata-rata usia pada kelompok intervensi terbesar usia 20-35 tahun sebesar 73.3\% dan rata-rata usia pada kelompok kontrol terbesar usia 20-35 tahun sebesar $80 \%$.

Tabel. 2

Distribusi Frekuensi Karakteristik Responden Berdasarkan Status Ekonomi

\begin{tabular}{ccccc}
\hline \multirow{2}{*}{ Variabel } & \multicolumn{2}{c}{ Kelompok Intervensi } & \multicolumn{2}{c}{ Kelompok Kontrol } \\
\cline { 2 - 5 } & Frekuensi & $\begin{array}{c}\text { Presentasi } \\
\%\end{array}$ & Frekuensi & $\begin{array}{c}\text { Presentasi } \\
\%\end{array}$ \\
\hline UMR & 14 & 93,3 & 15 & $100 \%$ \\
\hline Dibawah UMR & 1 & 6,7 & 0 & 0 \\
\hline
\end{tabular}

Berdasarkan tabel 2 menunjukkan bahwa rata-rata pendapatan pada kelompok intervensi adalah UMR sebesar 93,3\% dan rata-rata pendapatan pada kelompok intervensi adalah UMR sebesar $100 \%$.

Tabel. 3

Distribusi Frekuensi Karakteristik Responden Berdasarkan Pendidikan, Pekerjaan, Paritas, Persalinan

\begin{tabular}{lcccc}
\hline \multirow{2}{*}{ Variabel } & \multicolumn{2}{c}{ Kelompok Intervensi } & \multicolumn{2}{c}{ Kelompok Kontrol } \\
\cline { 2 - 5 } & Frekuensi & Presentasi (\%) & Frekuensi & Presentasi (\%) \\
\hline Pendidikan & 2 & & & \\
SD & 4 & 13,3 & 2 & 13,3 \\
SMP & 8 & 26,7 & 7 & 46,7 \\
SMA & 1 & 53,3 & 6 & 40 \\
PT & 6 & 6,7 & & \\
\hline Pekerjaan & 9 & 40 & 5 & 33,3 \\
Swasta & & 60 & 10 & 66,7 \\
IRT & 4 & & & 20 \\
\hline Paritas & 11 & 26,7 & 3 & 80 \\
Primigravida & 73,3 & 12 & 60 \\
Multigravida & 9 & & & 40 \\
\hline Persalinan & 6 & 60 & 9 & \\
Spontan & & 40 & 6 & \\
SC & & & & \\
\hline
\end{tabular}

Berdasar tabel 3 menunjukkan bahwa berdasarkan pendidikan responden memiliki tingkat pendidikan menengah atas. Hal ini ditunjukkan dengan presentasi responden dengan pendidikan menengah atas sebesar 53,3\% pada kelompok intervensi dan $40 \%$ pada kelompok kontrol. Berdasarkan pekerjaan responden pada kelompok ibu rumah tangga (IRT) sebesar 60\% pada kelompok intervensi dan pada kelompok kontrol sebesar $66,7 \%$. Berdasarkan paritas responden pada kelompok multigravida sebesar 73,3\% pada kelompok intervensi dan $80 \%$ pada kelompok kontrol . berdasarkan cara persalinan responden pada kelompok cara persalinan spontan sebesar $60 \%$ pada kelompok intervensi sedangkan pada kelompok kontrol sebesar $60 \%$. 


\section{Analisis Bivariat}

Tabel. 4

Uji Beda Pengaruh Pemberian Terapi Herbal Steam Bath dan Massage Terapi terhadap Pencegahan Postpartum Blues

\begin{tabular}{llc}
\hline & & $p$-value \\
\hline Post-pre & Negative Ranks & $0,001^{*}$ \\
& Positive ranks & \\
& Ties & \\
\hline
\end{tabular}

Berdasarkan tabel 4 menunjukkan dapat diketahui bahwa ada perbedaan pemberian herbal steam bath dan massage terapi terhadap pencegahan postpartum blues sebelum dan sesudah perlakuan karena p-value $<0,05$.

Tabel. 5

Uji Beda Pengaruh Pemberian Perawatan Nifas Konvensional terhadap Pencegahan Postpartum Blues

\begin{tabular}{llc}
\hline & $p$-value \\
\hline Post-pre & Negative Ranks & $0,011^{*}$ \\
& Positive ranks & \\
& Ties & \\
\hline
\end{tabular}

Berdasarkan tabel 5 dapat diketahui bahwa ada perbedaan pemberian perawatan nifas konvensional terhadap pencegahan postpartum blues sebelum dan sesudah perlakuan karena p-value $<0,05$.

Tabel. 6

Perbedaan antara Post Test Setelah Diberikan Intervensi Herbal Steam Bath dan Massage Terapi dengan Post Tes Perawatan Nifas Konvensional

\begin{tabular}{lll}
\hline & & p-value \\
\hline Post & Intervensi & $0,000 *$ \\
& Kontrol & $*$ \\
\hline
\end{tabular}

Berdasarkan tabel 6 dapat diketahui bahwa herbal steam bath dan massage terapi lebih efektif dibandingkan dengan perawatan nifas konvensional dalam pencegahan post partum blues dengan $\mathrm{p}$-value $<0,05$.

\section{Analisis Multivariat Variabel Confounding}

Tabel. 7

Pengaruh Variabel Confounding Usia Ibu, Pendidikam, Pekerjaan,

Cara Persalinan, Paritas, Pendapatan

\begin{tabular}{lcccc}
\hline \multicolumn{1}{c}{ Variabel } & Sig. & R Square & $R$ & P-Value \\
\hline Umur & 0.130 & & & 0.441 \\
Pendidikan & 0.150 & & & \\
Pekerjaan & 0.355 & 0.209 & 0.457 & \\
Pendapatan & 0.347 & & & \\
Paritas & 0.914 & & & \\
Cara persalinan & 0.900 & & & \\
\hline
\end{tabular}


Berdasarkan tabel 7 diatas didapatkan bahwa variable confounding umur, pendidikan, pekerjaan, pendapatan, paritas dan cara persalinan tidak memiliki pengaruh terhadap postpartum blues dan secara bersama-sama juga tidak memiliki pengaruh terhadap postpartum blues.

\section{PEMBAHASAN \\ Karakteristik Responden Umur}

Karakteristik responden berdasarkan umur dalam penelitian ini adalah umur 2035 tahun dan umur <35 tahun. Karakteristik responden berdasarkan umur menunjukan bahwa presentasi responden intervensi terbesar umur 20-35 tahun. Hasil uji homogenitas pada umur menunjukkan $p$-value $>0,05$ yang menyatakan bahwa rerata umur sama antara kelompok intervensi dan kontrol, artinya tidak ada perbedaan rerata umur yang bermakna antara kelompok intervensi dan kelompok kontrol dalam pencegahan postpartum blues. Penelitian ini sejalan dengan penelitian Ibrahim (2012) menunjukkan responden yang paling banyak mengalami depresi postpartum sebagian besar responden dengan kelompok umur 25-29 tahun sebanyak 40,8\%.

Hal ini berbeda dengan penelitian yang dilakukan Irawati (2014) menunjukkan bahwa umur yang mengalami postpartum blues adalah umur $<20$ tahun dan $>35$ tahun, umur tersebut merupakan umur berisiko bagi perempuan untuk melahirkan seorang bayi (Daman, 2015). Hal ini sesuai dengan data BKKBN (2012) yang menyatakan bahwa umur ideal wanita untuk hamil dan melahirkan adalah rentang umur 20-35 tahun, umur 20-35 tahun merupakan umur produksi yang sehat dimana pada rentang umur tersebut jarang terjadi komplikasi baik selama kehamilan, proses persalinan maupun masa nifas karena secara fisiologis dan psikologis organ-organ tubuh serta dalam segi emosional sudah matang untuk bereproduksi.

\section{Pekerjaan}

Kategori pekerjaan dalam penelitian ini adalah bekerja dan tidak bekerja. Ibu yang bekerja yaitu ibu yang melakukan kegiatan baik selama hamil dan setelah melahirkan yang dilakukan di luar rumah dengan tujuan untuk memperoleh penghasilan seperti PNS, karyawan swasta, buruh, dan wiraswasta, sedangkan ibu yang tidak bekerja adalah ibu rumah tangga. Karakteristik responden berdasarkan pendidikan menunjukkan bahwa presentasi ibu yang bekerja maupun tidak bekerja pada kelompok intervensi seimbang sedangkan pada kelompok kontrol terlihat bahwa sebagian besar ibu tidak bekerja. Hasil uji homogenitas pada pekerjaan menunjukkan p-value > 0,05 yang menyatakan pekerjaan responden homogen yang artinya rerata pendidikan sama antara kelompok intervensi dan kontrol tidak ada perbedaan rerata pekerjaan yang bermakna antara kelompok intervensi dan kelompok kontrol dalam pencegahan postpartum blues.

Tetapi hal ini sesuai dengan Alwi (2005) yang menyatakan bahwa pengetahuan berhubungan dengan pekerjaan dimana secara umum seorang yang bekerja maka pengetahuan akan tinggi karena banyak mendapatkan informasi penting yang dapat menunjang pengetahuan. Berdasarkan penelitian Dina Yusdiana (2011) menyatakan pekerjaan proporsi ibu yang mengalami postpartum blues korelasi pekerjaan ibu dengan kejadian stress pasca trauma, pekerjaan apapun yang dilakukan ibu cenderung relative. 


\section{Pendidikan}

Latar belakang pendidikan dalam penelitian ini dikategorikan berdasarkan tingkat pendidikan formal yang ditempuh responden berdasarkan ijazah dengan kategori SD, SMP, SMA, dan PerguruanTinggi. Karakteristik responden berdasarkan pendidikan menunjukkan sebagian besar ibu memiliki tingkat pendidikan menengah atas. Hal ini ditunjukkan dengan presentasi ibu dengan pendidikan menengah atas sebesar 53,3\% pada kelompok intervensi sedangkan presentasi ibu dengan pendidikan sekolah menengah pertama sebesar 46,7\% pada kelompok kontrol. Hasil uji homogenitas pada pendidikan menunjukkan $p$-value $>0,05$ yang menyatakan bahwa rerata pendidikan sama antara kelompok intervensi dan kontrol, artinya tidak ada perbedaan rerata pendidikan yang bermakna antara kelompok intervensi dan kelompok kontrol dalam pencegahan postpartum blues. Hasil penelitian ini sejalan dengan penelitian Murwati 2015) didapatkan bahwa responden yang mengalami depresi postpartum adalah sekolah menengah atas (SMA-SMK) sejumlah 19 orang (63.3\%) dan sebagian kecil berpendidikan dasar (SD-SMP) sejumlah 11 orang $(36,7 \%)$.

Penelitian ini juga sejalan dengan penelitian yang dilakukan Sope (2009) didapatkan bahwa hasil proporsi ibu postpartum yang mengalami depresi 51,7\% terjadi pada ibu berpendidikan sedang (pendidikan menengah). Hasil penelitian ini menunjukkan bahwa sebagian besar responden memiliki pendidikan yang tinggi. Pendidikan berpengaruh terhadap pengetahuan dan kesiapan seorang ibu dalam menjalani kehamilan dan persalinan. Berdasarkan karakteristik pendidikan, pengetahuan ibu masih kurang tentang system reproduksi dan gangguan-gangguan dalam masa setelah melahirkan atau masa nifas untuk dapat menerima peran barunya sebagai ibu belum dipahami (Moura, 2016).

\section{Cara Persalinan}

Kategori cara persalinan dalam penelitian ini adalah cara persalinan spontan dan seksio sesarea. Persalinan spontan adalah proses lahirnya bayi dengan presentasi kepala dengan tenaga ibu sendiri, tanpa bantuan alat-alat atau pertolongan istemewa serta tidak melukai ibu dan bayi yang umumnya berlangsung kurang dari 24 jam, sedangkan persalinan seksio sesarea adalah suatu persalinan buatan dimana janin dilahirkan melalui suatu insisi pada dinding perut dan dinding rahim dengan syarat rahim dalam keadaan utuh serta berat janin diatas 500 gram. Karakteristik responden berdasarkan cara persalinan menunjukkan cara persalinan ibu adalah persalinan spontan. Hal ini ditunjukkan dengan presentasi cara persalinan spontan pada kelompok intervensi dan kontrol seimbang sebesar $60 \%$. Hasil uji homogenitas pada pendidikan menunjukkan $p$ value $>0,05$ yang menyatakan bahwa rerata pendidikan sama antara kelompok intervensi dan kontrol, artinya tidak ada perbedaan rerata pendidikan yang bermakna antara kelompok intervensi dan kelompok kontrol dalam pencegahan postpartum blues.

Faktor yang mempengaruhi terjadinya postpartum blues diantaranya pengalaman kehamilan dan persalinan yang melingkupi komplikasi dan persalinan dengan tindakan, dukungan social diantaranya dukungan keluarga, keadaan bayi yang tidak sesuai harapan.

Menurut Noor Hidayah (2016) menjelaskan dalam penelitiannya pengalaman selama persalinan pada responden yaitu masih merasa cemas dan takut terjadi sesuatu saat persalinan dan responden juga mengalami pengalaman persalinan dengan komplikasi baik itu seksio sesarea ataupun persalinan lama (freeman, 2014). Sejalan dengan penelitian Dina Yusdiana (2011) ibu yang mengalami stress melakukan partus 
dengan cara spontan (tidak terencana) sebesar 83,3\%, tingginya kejadian stress ibu setelah melakukan persalinan pada umumnya terjadi terhadap ibu dengan persalinan spontan, karena cara persalinan ini tidak direncanakan, sehingga kesiapan ibu baik secara fisik maupun psikologi belum siap sehingga berdampak terhadap stabilitas emosi atau perasaan kecemasan.

\section{Paritas}

Kategori paritas dalam penelitian ini adalah primigravida dan multigravida. Primigravida adalah keadaan dimana seorang wanita mengalami masa kehamilan untuk pertama kalinya, sedangkan, multigravida adalah keadaan dimana seseorang yang hamil lebih dari 1 sampai 5 kali. Karakteristik responden berdasarkan paritas menunjukkan menunjukkan yang mengalami postpartum blues adalah ibu multigravida sebesar 73,3\% pada kelompok intervensi dan $80 \%$ pada kelompok kontrol. Hasil uji homogenitas pada pendidikan menunjukkan $p$-value $>0,05$ yang menyatakan bahwa rerata pendidikan sama antara kelompok intervensi dan kontrol, artinya tidak ada perbedaan rerata pendidikan yang bermakna antara kelompok intervensi dan kelompok kontrol dalam pencegahan postpartum blues. Paritas adalah status melahirkan pada seseorang wanita.

Menurut Freudenthal (1999) menyatakan postpartum blues yang dialami seorang perempuan setelah melahirkan terjadi karena sedikit atau tidak ada sama sekali bantuan dalam merawat anak. Hal tersebut dapat terjadi pada setiap perempuan, baik primigravida maupun multigravida.

\section{Status Ekonomi}

Kategori status ekonomi pada penelitian ini adalah pendapatan perbulan keluarga UMR dan dibawah UMR. Karakteristik responden berdasarkan status ekonomi menunjukkan yang mengalami postpartum blues adalah pendapatan UMR pada sebesar 93,3\% pada kelompok intervensi dan pendapatan pada kelompok sebesar 100\%. Hasil uji homogenitas pada pendidikan menunjukkan $p$-value $>0,05$ yang menyatakan bahwa rerata pendidikan sama antara kelompok intervensi dan kontrol, artinya tidak ada perbedaan rerata pendidikan yang bermakna antara kelompok intervensi dan kelompok kontrol dalam pencegahan postpartum blues. Hasil penelitian ini sejalan dengan penelitian Irawati (2014) didapatkan hasil penelitian menunjukkan tidak terdapat hubungan yang signifikan antara pendapatan dengan kejadian postpartum blues dengan nilai $\mathrm{p}=0.182$.

Hasil ini tidak sesuai dengan penelitian Reid (2015) bahwa pendapatan yang rendah berkontribusi terhadap terjadinya postpartum blues. Kondisi sosio ekonomi seringkali membuat psikologi ibu terganggu. Pada keluarga yang mampu mengatasi pengeluaran untuk biasa perawatan ibu selama persalinan, serta tambahan dengan hadirnya bayi baru ini mungkin hampir tidak merasakan beban keuangan sehingga tidak menganggu proses transisi menjadi orang tua. Akan tetapi keluarga yang menerima kelahiran seorang bayi dengan suatu beban finansial dapat mengalami peningkatan stress, stress ini biasa mengganggu perilaku orang tua sehingga membuat masa transisi untuk memasuki pada peran menjadi orang tua akan menjadi lebih sulit. 


\section{Analisis Bivariat \\ Pengaruh Pemberian Terapi Herbal Steam Bath dan Massage Terapi terhadap Pencegahan Postpartum Blues}

Hasil penelitian menunjukkan bahwa ada perbedaan pemberian terapi herbal steam bath dan massage terapi terhadap pencegahan postpartum blues sebelum dan sesudah perlakuan yang ditunjukkan dengan hasil $p$ value $<0,05$. Sebelum dan sesudah dilakukan intervensi herbal steam bath dan massage terapi didapatkan hasil $p$ value 0,001 maka dapat disimpulkan bahwa ada perbedaan yang signifikan sebelum dan sesudah dilakukan intervensi herbal steam bath dan massage terapi. Dengan kata lain intervensi kombinasi herbal steam bath dan massage terapi efektif mencegah terjadinya postpartum blues. Pada penelitian ini herbal steam bath merupakan terapi sauna yang dilakukan untuk meningkatkan kesehatan dan kecantikan yang merangsang sirkulasi darah dan bisa membantu mengeluarkan bahan bersifat racun dari sel dan jaringan. Sehingga tubuh menjadi sehat dan jiwa pun tenang dan nyaman.

Pada proses herbal steam bath, jenis bahan tumbuhan yang digunakan pada ramuan seperti serai wangi dan daun jeruk perut bahan tersebut mengandung bahan senyawa bioaktif terutama minyak atsiri, alkoid. Minyak atsiri meupakan senyawa bioaktif yang terdapat yang terdapat hampir diseluruh bagian tumbuhan diatas daun, batang, buah, biji dan rimpang yang berfunsi sebagai aromaterapi dengan efek menenangkan dan menyegarkan untuk kesehatan, sehingga dapat bermanfaat untuk memulihkan kesehatan ibu nifas dengan postpartum blues. Menurut Watuseke dalam Zumsteg, Weekerle (2007) mandi uap tradisional dengan menggunakan tanaman herbal atau obat obatan untuk perawatan ibu setelah melahirkan atau ibu pada masa nifas. Pada proses herbal steam bath bertujuan untuk penyembuhan setelah melahirkan atau masa nifas untu mengembalikan kondisi fisik dan psikis ibu seperti sebelum hamil dan melahirkan. Dalam penelitian Sinuhaji (2014) melalui proses oukup/sauna ibu dipaksa berkeringat, yang dimana keringat mempunyai manfaat bagi ibu nifas yaitu keringat membuat suhu tubuh tetap dingin, dapat membersihkan racun dari tubuh, dapat mempercantik kulit, memperlancar sirkulasi darah, menurunkan stress. Dalam herbal steam bath ini menggunakan rempah-rempah yang mengandung minyak atsiri didalamnya. Minyak atsiri merupakan senyawa bioaktif yang terdapat hampir diseluruh bagian tumbuhan di atas daun, batang, buah biji dan rimpang yang berfungsi sebagai aromaterapi dengan efek menenangkan dan menyegarkan untuk kesehatan dan kegunaan lain. Sedangkan untuk massage terapi back efflurage bertujuan untuk meningkatkan sirkulasi darah, memberi tekanan, menghangatkan otot abdomen dan meningkatkan relaksasi fisik dan mental.

\section{Perbedaan antara Post Test Setelah Diberikan Intervensi Herbal Steam Bath dan Massage Terapi dengan Post Tes Perawatan Nifas Konvensional}

Berdasarkan hasil penelitian dari hasil uji wilxocon menunjukkan perbedaan yang signifikan antara kelompok intervensi dan kontrol yang ditunjukkan dengan hasil pvalue 0,000 , dapat diketahui bahwa herbal steam bath dan massage terapi lebih efektif dibandingkan dengan perawatan nifas konvensional dalam pencegahan post partum blues. mencegah terjadinya postpartum blues. Pada penelitian ini herbal steam bath merupakan terapi sauna yang dilakukan untuk meningkatkan kesehatan dan kecantikan yang merangsang sirkulasi darah dan bisa membantu mengeluarkan bahan bersifat racun dari sel dan jaringan. Sehingga tubuh menjadi sehat dan jiwa pun tenang dan nyaman. 
Pada proses herbal steam bath, jenis bahan tumbuhan yang digunakan pada ramuan seperti serai wangi dan daun jeruk perut bahan tersebut mengandung bahan senyawa bioaktif terutama minyak atsiri, alkoid. Minyak atsiri meupakan senyawa bioaktif yang terdapat yang terdapat hampir diseluruh bagian tumbuhan diatas daun, batang, buah, biji dan rimpang yang berfunsi sebagai aromaterapi dengan efek menenangkan dan menyegarkan untuk kesehatan, sehingga dapat bermanfaat untuk memulihkan kesehatan ibu nifas dengan postpartum blues. Menurut Watuseke dalam Zumsteg, Weekerle (2007) mandi uap tradisional dengan menggunakan tanaman herbal atau obat obatan untuk perawatan ibu setelah melahirkan atau ibu pada masa nifas. Pada proses herbal steam bath bertujuan untuk penyembuhan setelah melahirkan atau masa nifas untu mengembalikan kondisi fisik dan psikis ibu seperti sebelum hamil dan melahirkan. Sedangkan untuk massage terapi back efflurage bertujuan untuk meningkatkan sirkulasi darah, memberi tekanan, menghangatkan otot abdomen dan meningkatkan relaksasi fisik dan mental (Manurung, 2011).

\section{SIMPULAN}

Herbal steam bath dan massage terapi lebih efektif dibandingkan dengan perawatan nifas konvensional dalam pencegahan post partum blues.

\section{SARAN}

\section{Peneliti Selanjutnya}

Peneliti selanjutnya diharapkan dapat mengembangkan penelitian ini menjadi penelitian kualitatif-kuantitatif agar menambah keefektifan hasil penelitian serta diharapkan dapat melakukan penelitian dalam jangka waktu yang lebih lama untuk mengetahui efektifitas kombinasi herbal steam bath dan massage terapidalam mencegah postpartum blues.

\section{Dinas Kesehatan}

Dinas Kesehatan diharapkan dapat menerapkan dan melatih tenaga kesehatan mengenai herbal steam bath dan massage terapi agar dapat diteruskan kepada masyarakat khususnya ibu nifas untuk menambah pengetahuan dalam mencegah post partum blues.

\section{Tenaga Kesehatan}

Tenaga kesehatan di tingkat pelayanan yaitu bidan, perawat, maupun dokter diharapkan lebih aktif dalam memberi edukasi mengenai post partum blues.

\section{DAFTAR PUSTAKA}

A.C. de Moura ea. (2016). Global Histone H4 Acetylation in the Olfactory Bulb of Lactating Rats with Different Patterns of Maternal Behavior. Cell Mol Neurobiol; 36 1209-13

Alwi. (2005). Buku ajar fundamental keperawatan. Jakarta: EGC

BKKBN. (2012) . Remaja Genre dan Perkawinan Dini. Jakarta: Direktorat Remaja Dan Perlindungan Hak- Hak Reproduksi

Daman, F. A., Salat, S. Y. S. (2015). Faktor Risiko Tingkat Stres pada Ibu Nifas di Wilayah Kerja UPT Puskesmas Legung Timur Kecamatan Batang-Batang Kabupaten Sumenep Tahun 2014. Wiraraja Medika, 5(1) 
Deligiannidis, K. M., Freeman, M. P. (2014). Complementary and Alternative Medicine Therapies for Perinatal Depression. Best Practice \& Research Clinical Obstetrics \& Gynaecology, 28(1), 85-95

Freudenthal, N. M., Crost, M., \& Kaminski, M. (1999). Severe Post-Delivery Blues: Associated Factors. Arch Womens Ment Health, 2, 37-44

Gibson, J., McKenzie-McHarg K., Shakespeare, J., Price, J., Gray, R. (2009). A Systematic Review of Studies Validating the Edinburgh Postnatal Depression Scale in Antepartum and Postpartum Women. Acta Psychiatrica Scandinavica, $119(5), 350-64$

Hidayah, N., Rahmawati, J. E. D., Azizah, N. (2017). Support Sistem, Pengalaman Persalinan dengan Resiko Post Partum Blues di BPM Yayuk Kalbariyanto Kudus Tahun 2016. Jurnal Ilmu Keperawatan dan Kebidanan, 8(2), 44-52

Ibrahim, C. S. (2012). Perawatan Kebidanan. Jakarta: Bhratara Niaga Media

Irawati, D., Yuliani, F. (2014). Pengaruh Faktor Psikososial dan Cara Persalinan terhadap Terjadinya Post Partum Blues pada Ibu Nifas. Hospital Majapahit, 6(1), $1-7$

Kirana, Y. (2016). Hubungan Tingkat Kecemasan Post Partum dengan Kejadian Post Partum Blues di Rumah Sakit Dustira Cimahi. Keperawatan, 3(1)

Manurung, S, Lestari, T. R., Wiradwiyana, B., Karma, A., Paulina, K. (2011). Efektivitas Terapi Musik terhadap Pencegahan Postpartum Blues pada Ibu Primipara di Ruang Kebidanan RSUP Cipto Mangunkusumo Jakarta Pusat. Buletin Penelitian Sistem Kesehatan, 14

Murwati, M., Istiqomah, H. (2015). Pengaruh Lama dan Frekuensi Massage Terapi Ibu Nifas terhadap Depresi Postpartum. Interest. Jurnal Ilmu Kesehatan, 4(2), 82-196

Reid, K. M., Taylor, M. G. (2015). Stress and Maternal Postpartum Depression: the Importance of Stress Type and Timing Popul Res Policy Rev 34, 851e875

Sinuhaji, L. N. B. (2014). Oukup dalam Perawatan Kesehatan Ibu Nifas pada Suku Karo Di Berastagi Kabupaten Karo Tahun

Yusdiana, D. (2011). Perbedaan Kejadian Stres Pasca Trauma pada Ibu Post Partum dengan Seksio Sesaria Emergenci, Partus Pervagina dengan Vakum dan Partus Spontan. Jurnal Keperawatan Indonesia, 14(3), 207-212

Zumsteg, I. S., Weckerle, C. S. (2007). Bakera, a Herbal Steam Bath for Postnatal Care in Minahasa (Indonesia): Documentation of the Plants Used and Assessment of the Method. Journal of Ethnopharmacology, 111(3), 641-50 